\title{
BMJ Open Telework in a pandemic context: protocol of a participatory study on the effects of teleworking conditions on the well-being and social participation of workers
}

\author{
Alexandra Lecours (1) ,1,2 Marie-Hélène Gilbert, ${ }^{3}$ Marie-Michèle Lord, ${ }^{1}$ \\ Charlotte Labrecque, ${ }^{2}$ Frédéric Boucher ${ }^{2}$
}

To cite: Lecours A, Gilbert M-H, Lord M-M, et al. Telework in a pandemic context: protocol of a participatory study on the effects of teleworking conditions on the well-being and social participation of workers. BMJ Open 2021;11:e051099. doi:10.1136/ bmjopen-2021-051099

- Prepublication history and additional supplemental material for this paper are available online. To view these files, please visit the journal online. (http://dx.doi.org/10.1136/ bmjopen-2021-051099).

Received 09 March 2021 Accepted 11 August 2021

D) Check for updates

(c) Author(s) (or their employer(s)) 2021. Re-use permitted under CC BY-NC. No commercial re-use. See rights and permissions. Published by BMJ.

${ }^{1}$ Département d'ergothérapie, Université du Québec à TroisRivières, Trois-Rivieres, Quebec, Canada

${ }^{2}$ Center for Interdisciplinary Research in Rehabilitation and Social Integration, Quebec, Quebec, Canada

${ }^{3}$ Département de management, Université Laval, Quebec, Quebec, Canada

Correspondence to

Dr Alexandra Lecours;

Alexandra.Lecours@uqtr.ca

\section{ABSTRACT}

Introduction Although several authors have been interested in the well-being and social participation of teleworkers in the context of the COVID-19 pandemic, it appears that most of the recommendations issued are based on literature reviews or expert opinions; yet few authors have documented the perspectives of the workers. The aim of this study is to explore workers' perspectives of teleworking in the context of the COVID-19 pandemic regarding the effects on their well-being and social participation.

Methods and Analysis Using a participatory study protocol involving the collaboration of a community organisation defending workers' rights, the first step will be to conduct focus groups to qualitatively describe workers' perspectives of their teleworking conditions. Then, an online questionnaire will be administered to a large pool or workers to quantitatively explore the influence of individual, organisational and environmental variables on the well-being and social participation of workers. The thematic and statistical analyses of the data collected will indicate successful practices to be adopted by workers and organisations. These successful practices will be validated by workers through a Technique for Research of Information by Animation of a Group of Experts group and will serve as concrete tools to better support workers' participation in teleworking.

Ethics and dissemination The approval of the research ethics board of the Centre intégré universitaire de santé et de services sociaux de la Capitale Nationale has been obtained. Findings will be shared with various stakeholders including workers, employers, insurers and unions.

Findings will be disseminated in webinars, peer-reviewed journals and lectures.

\section{INTRODUCTION}

The COVID-19 pandemic has led to an unprecedented health crisis for the contemporary world. According to public health directives to slow down the spread of the virus, strict measures, particularly to ensure physical distancing, had to be respected by all citizens,
Strengths and limitations of this study

- The use of qualitative and quantitative methods makes it possible to exploit all the richness of data and to deepen the understanding of the phenomenon studied.

- The constant contribution of a community partner ensures that the study is anchored in the reality of knowledge users.

- The final stage of consensus building includes workers. This concern to include the public maximises the chances that the results will be applied.

- This study is being conducted in Canada. The transferability of the results to other contexts cannot be guaranteed.

including corporate citizens. As a result, millions of workers quickly found themselves having to carry out their activities from home without their organisations having prepared them for it. In Canada, in June 2020, 39\% of Canadian workers carried out their work remotely, whereas this proportion reached only $17 \%$ before the pandemic. ${ }^{1}$ In the USA, $71 \%$ of people worked from home all or most of the time during the pandemic. ${ }^{2}$

Due to continued exposure to stress, loss and change caused by the COVID-19 pandemic, negative consequences on individuals' health have occurred. ${ }^{3}$ In Canada, the proportion of people reporting good mental health in 2020 has decreased by $13 \%$ as compared with the previous year. ${ }^{4}$ In the USA, $25 \%$ of workers have reported a decrease in job satisfaction during the pandemic. ${ }^{2}$ Canadians experiencing significant financial repercussions from the pandemic have had twice the proportion of poor mental health and have been more likely to develop uncertainties about the future of employment. ${ }^{5}$ However, 
the possibility of teleworking during the pandemic has reduced the likelihood of experiencing a work stoppage or layoff, which decreases this uncertainty about the future of employment and income. ${ }^{6}$

Since the last decades, scientific articles report the positive effects of teleworking for certain indicators of participation and well-being, such as the reduction of time constraints or the improvement of autonomy. ${ }^{7-9}$ Other authors reported teleworking 'best practices', such as access to an appropriate workspace, training and technical support. ${ }^{10}{ }^{11}$ However, the urgent and unplanned shift to teleworking may have changed the relationship between this way of working and well-being in work participation. Indeed, recent studies suggested that teleworking during the pandemic has notably let to a feeling of isolation among workers, ${ }^{12}$ sedentary lifestyle ${ }^{13}$ and stress linked to rapid digital learning. ${ }^{14}$ Some authors recently identified teleworking practices to be favoured in the context of the pandemic with a view to supporting organisations and workers in this alternative way of working. ${ }^{915} 16$ For example, allowing flexible working hours according to the realities at home (eg, childcare) has been suggested. It has also been recommended to use various technological tools to offer the worker support from the organisation, ${ }^{11}$ manager ${ }^{17}$ and colleagues. ${ }^{11} 12$ Other authors have suggested that organisations should adopt a teleworking policy to better support their employees. ${ }^{7}$ Finally, it has been suggested to encourage workers to remain physically active $^{18}$ and to develop new work routines. ${ }^{18} 19$ Although several authors have been interested in the well-being and social participation of teleworkers in the context of the pandemic, it appears that most of the recommendations issued are based on literature reviews or expert opinions; yet few authors have documented the perspectives of the workers. As a result, workers' perspectives of the impact of teleworking during the pandemic on their well-being and social participation remain little documented.

Considering that teleworking will last beyond the pandemic ${ }^{4}$ and that workers are at the heart of this transformation of the world of work, it is important to document how they have experienced the situation to date in order to be able to build the situation in the future. To ensure that teleworking practices arising from the experience during the pandemic respect workers' rights and do not affect their well-being or social participation negatively, it is important to consult them to understand their realities and needs. Documenting the perspectives of workers with the experience of teleworking during the pandemic appears to be essential to fine-tune existing recommendations and generate new ones. In this way, the chances of these practices being adopted and contributing to the well-being of workers and the maintenance of satisfactory social participation are increased.

The aim of this study is to explore workers' perspectives of teleworking in the context of the COVID-19 pandemic regarding the effects on their well-being and social participation. The three specific objectives will be to: (1) describe workers' perspectives of their teleworking conditions during the pandemic; (2) identify individual, organisational and environmental variables influencing the well-being and social participation of workers and (3) suggest successful practices to enhance teleworkers' wellbeing and social participation.

\section{METHOD AND ANALYSIS Protocol}

This study will be conducted using a participatory research protocol. ${ }^{20-22}$ This protocol facilitates working together with different stakeholders involved in the world of work (eg, workers, insurers, employers and unions), decompartmentalising research and practice as well as optimising the acceptance and application of research results in practice. ${ }^{22}$ The research initiative will revolve around a steering committee ${ }^{23}$ comprising three researchers and three representatives of a community partner, which is a Canadian organisation defending workers' (This Canadian organisation defending workers' rights will hereafter be referred to as 'the partner.')]. The researchers, acting as mentors, will facilitate the involvement of steering committee members and help them understand the research process. ${ }^{24}{ }^{25} \mathrm{~A}$ half-day meeting will be held every 2 months to refine the research question, confirm the methodological choices and support the collection of data and interpretation of results. These meetings will also serve to cobuild effective strategies to share results with stakeholders in the world of work.

\section{Theoretical framework}

This study will be based on an integrative understanding of workers' well-being, which makes it a multidimensional concept including both psychological (eg, cognition, affect) and physical (eg, life habits, physiological disorders) indicators. ${ }^{26}$ The well-being of workers also encompasses positive (eg, motivation, positive emotions) and negative (eg, stress, fatigue) aspects. ${ }^{27} 28$ The concept of social participation entails an individual taking part in an action that contributes to a social group, as in the role of a worker. ${ }^{29}$ Finally, workers' well-being and social participation are both influenced by individual, organisational and environmental variables. ${ }^{29} 30$

\section{Participants, procedure and analysis of data}

Three stages of research have been planned, as shown in figure 1 .

\section{Stage A}

Virtual focus groups ${ }^{31}$ (using the Zoom platform) will be conducted with workers with the experience of teleworking in the context of the pandemic. Eight participants will be brought together in each group because this number is big enough for useful discussions, ${ }^{31}$ yet small enough to let everybody speak. ${ }^{32}$ Participants will have to meet the following criteria: (1) being 18 years old or older; (2) having experienced teleworking during the COVID-19 pandemic and (3) being fluent in French. Diversity in 


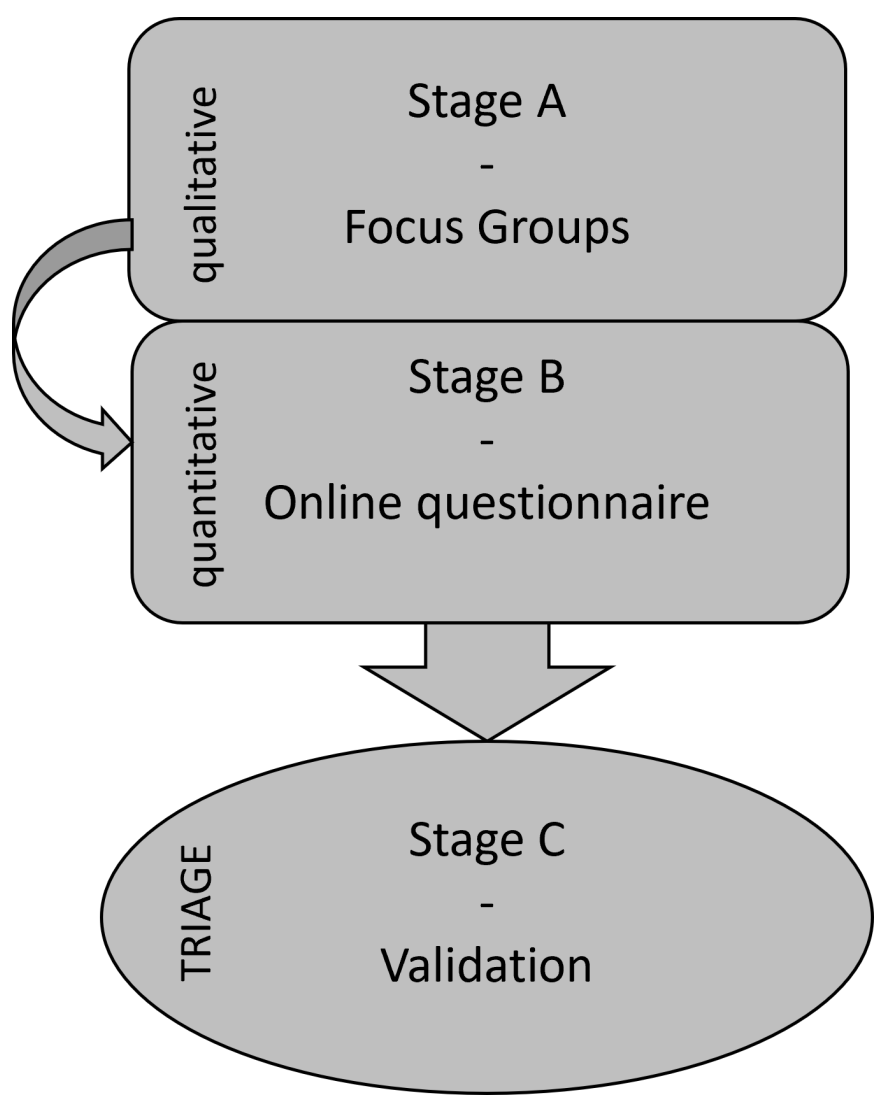

Figure 1 Study design. TRIAGE, Technique for Research of Information by Animation of a Group of Experts

terms of age, sex and employment type will be ensured at the time of recruitment. Participants will be recruited through publicity among the researchers' network and on social media, as well as among the partner's users and collaborators (eg, other organisations defending workers' rights, unions, insurers and employers). In addition to sociodemographic information (eg, marital status) and information allowing to paint a portrait of workers (eg, previous teleworking experience), workers' perspectives of various subjects regarding their impact on well-being and social participation will be collected. For instance, (1) teleworking conditions (eg, physical and technological environment) and (2) individual and organisational practices (eg, work-life balance) will be documented. Best practices and challenges, needs and resources, facilitators and obstacles related to this forced teleworking situation will also be documented. The discussion questions for the focus groups (see online supplemental annex A) will be developed by the steering committee and pretested on two people with the same characteristics as the participants. The number of focus groups to be conducted will be defined over the course of the study according to the redundancy of ideas shared by participants. ${ }^{33}$ It is estimated that two or three groups will be required to reach saturation. $^{34}$

\section{Analysis}

After fully transcribing the data and importing it into the QDA Miner software, a thematic analysis strategy in four stages will be employed ${ }^{35}$ : (1) repeated readings of the data corpus to develop a feeling of immersion; (2) initial coding (descriptive codes will be assigned to the meaning units found in the corpus); (3) conception of a code tree (the codes (microlevel) will be grouped into categories (mesolevel) and/or themes (macrolevel)) and (4) finalisation of the code tree by going back and forth between the raw data and the general structure to clarify and interpret the data while respecting the perspectives of participants. To ensure scientific rigour, the thematic analysis process will be carried out by two people and the inter-rater agreement will be periodically checked.

This first stage of the study will allow a better understanding of the complexity of the phenomenon studied and identification of the major stakes to orient the second stage of the research. This first stage is justified to support the next, which deals with workers' experiential knowledge.

\section{Stage B}

An online questionnaire will be administered to a large pool of workers (ie, few hundreds). The inclusion criteria and recruitment strategy for these participants (stage B) is the same as for stage A In addition to questions to better understand the situation of these workers (eg, marital status, dependent children, employment type and previous teleworking experience), they will be asked to share their perspectives of the variables identified in stage A. Therefore, (1) individual (eg, feeling of personal effectiveness, resilience), (2) organisational (eg, organisational availability and leadership style) and (3) environmental (eg, home office ergonomics, social support) variables as well as their perspective of various indicators of, (4) well-being (eg, stress, pain) and (5) social participation (eg, satisfaction, sense of belonging) will be documented using validated quantitative scales (eg, Areas of Worklife Scale, ${ }^{36}$ Recovery experience questionnaire ${ }^{37}$ ). Please see online supplemental annex B to consult the online questionnaire.

\section{Analysis}

These quantitative variables will be subjected to statistical analyses appropriate to their type (eg, descriptive, inferential). ${ }^{38}$ A statistician will see to the rigorous processing of statistics.

This second stage of the study will allow the impact of the documented variables on the well-being and social participation of workers to be explored, and to identify those that contribute to favourable teleworking conditions in the pandemic.

\section{Stage C}

The triangulation of qualitative and quantitative results obtained in stages $\mathrm{A}$ and $\mathrm{B}$ of the research may point to successful practices to be adopted by workers and organisations for this rapid shift to telework. This triangulation will take place during a steering committee meeting. The successful practices identified will be recorded in 
Start of project, ethics application and steering committee training

Stage A: qualitative data collection and thematic analyses

Stage B: quantitative data collection and statistical analyses

Stage C: triangulation, writing and webinar validation TRIAGE

Dissemination of results-communication and publication

TRIAGE, Technique for Research of Information by Animation of a Group of Experts.

a webinar and validated during a virtual Technique for Research of Information by Animation of a Group of Experts (TRIAGE) ${ }^{39} 40$ group (using the Zoom platform) with participants $(n=8)$ who took part in either stage A or B. The TRIAGE method allows discussions among participants to be structured to arrive at a consensus on specific ideas while facilitating the emergence of new ideas. ${ }^{39}$ This method was shown to be economical and rigorous to reach a consensus on emerging subjects. ${ }^{39}$ Various indicators (eg, applicability, relevance, clarity) will be documented.

\section{Analysis}

The data for the validation of the webinar will be analysed in situ, which is consistent with the TRIAGE method. ${ }^{39} 40$ This final validation will ensure that the practices recommended are used for workers and other stakeholders in the world of work. The results of the study, based on workers' experience, will also complement current knowledge on the impact of teleworking in the pandemic on the well-being and social participation of workers.

\section{Schedule}

The planned duration of this study is 12 months, starting from April 2021 and ending in March 2022. Table 1 presents the planned timetable for the study.

\section{Patient and public involvement}

To support the coproduction of knowledge, the research protocol envisages the participation of a Canadian organisation defending workers' rights throughout the study. This partner will ensure the involvement of the public, that is, workers, in this study. The active participation of this partner in the study will also ensure that its results are relevant to the reality of workers and other stakeholders in the world of work (eg, insurers, employers and unions).

\section{ETHICS AND DISSEMINATION}

The approval of the research ethics board of the Centre intégré universitaire de santé et de services sociaux de la Capitale Nationale has been obtained (project 2021-2239).

The entire partnership will take place as an integrated transfer of knowledge, that is, steering committee members, including representatives of the partner, will actively participate in the research stages to increase its relevance and benefits for users. Among other things, the partner already offers lectures to the public twice a month on Tuesday evenings. The results of the study will be presented during these lectures after each stage of research. Those who attend will have the opportunity to react to the results, which will be highly informative for the subsequent stages of the study. These lectures will also be posted on the web to reach a wider audience. Webinars will be organised for participants and decisionmakers from different stakeholders in the world of work. Results will also be disseminated in an open access scientific journal (eg, BMJ Open), lectures and seminars (eg, International Congress on Occupational Health) and lay articles on the partner's websites and social media.

Contributors $\mathrm{AL}, \mathrm{M}-\mathrm{HG}$ and $\mathrm{M}-\mathrm{ML}$ contributed to the study conception and design. Literature search was performed by AL and CL. Material preparation was done by $A L, C L$ and $F B$. The first draft of the manuscript was written by $A L$ and all the authors commented on the previous versions of the manuscript. All the authors read and approved the final manuscript.

Funding This work was supported by a research grant from the Social Sciences and Humanities Research Council of Canada (grant 1008-2020-1002).

Competing interests None declared.

Patient consent for publication Not required.

Provenance and peer review Not commissioned; externally peer reviewed.

Supplemental material This content has been supplied by the author(s). It has not been vetted by BMJ Publishing Group Limited (BMJ) and may not have been peer-reviewed. Any opinions or recommendations discussed are solely those of the author(s) and are not endorsed by BMJ. BMJ disclaims all liability and responsibility arising from any reliance placed on the content. Where the content includes any translated material, BMJ does not warrant the accuracy and reliability of the translations (including but not limited to local regulations, clinical guidelines, terminology, drug names and drug dosages), and is not responsible for any error and/or omissions arising from translation and adaptation or otherwise.

Open access This is an open access article distributed in accordance with the Creative Commons Attribution Non Commercial (CC BY-NC 4.0) license, which permits others to distribute, remix, adapt, build upon this work non-commercially, and license their derivative works on different terms, provided the original work is properly cited, appropriate credit is given, any changes made indicated, and the use is non-commercial. See: http://creativecommons.org/licenses/by-nc/4.0/.

ORCID iD

Alexandra Lecours http://orcid.org/0000-0002-4485-7829

\section{REFERENCES}

1 Zossou C. Partage des tâches domestiques : faire équipe pendant la pandémie: Statistique Canada, 2021.

2 Parker K, Horowitz J, Minkin R. How the coronavirus outbreak has and hasn't changed the way americans work, 2020. 
3 Belkin G, Appleton S, Langlois K. Reimagining mental health systems post COVID-19. Lancet Planet Health 2021;5:e181-2.

4 Statistique Canada. La COVID-19 au Canada : le point sur les répercussions sociales et économiques après six mois, 2020b.

5 Statistique Canada. Série d'enquêtes sur les perspectives canadiennes 1 : Répercussions de la COVID-19 sur la sécurité d'emploi et les finances personnelles, 2020, 2020a.

6 Messacar D, Morissette R, et Deng Z. Inégalités en matière de faisabilité du travail domicile pendant et après la COVID-19: Statistiques Canada, 2020.

7 Comité consultatif du travail et de la main-d'oeuvre. Avis sur Le télétravail.: Ministère Du Travail, de l'Emploi et de la Solidarité sociale, 2020.

8 Sardeshmukh SR, Sharma D, Golden TD. Impact of telework on exhaustion and job engagement: a job demands and job resources model. New Technol Work Employ 2012;27:193-207.

9 Jauvin N, Stock S, Laforest J. Le télétravail en contexte de pandémie. In: Inds publique, ed. Québec: Gouvernement du Québec, 2020: 15.

10 Greer TW, Payne SC. Overcoming telework challenges: outcomes of successful telework strategies. The Psychologist-Manager Journal 2014;17:87-111.

11 Oakman J, Kinsman N, Stuckey R, et al. A rapid review of mental and physical health effects of working at home: how do we optimise health? BMC Public Health 2020;20:1825.

12 Tremblay D-G, Demers G. Guide d'information et d'implantation. Le télétravail : enjeux et défis Université TÉLUQ, 2020.

13 McDowell CP, Herring MP, Lansing J, et al. Associations between employment changes and mental health: US data from during the COVID-19 pandemic. Front Psychol 2021;12:631510.

14 Bjursell C, Bergmo-Prvulovic I, Hedegaard J. Telework and lifelong learning. Front Sociol 2021;6:642277.

15 Bouziri $H$, Smith DRM, Descatha $A$, et al. Working from home in the time of COVID-19: how to best preserve occupational health? Occup Environ Med 2020;77:509-10.

16 Hallin H. Home-Based Telework during the Covid-19 pandemic, 2020.

17 Conseil du patronat du Québec. Guide pratique pour l'implantation Du télétravail en entreprise, 2020: 36.

18 Lopez-Leon S, Forero DA, Ruiz-Díaz P. Recommendations for working from home during the COVID-19 pandemic (and beyond). Work 2020;66:371-5.

19 Birimoglu Okuyan C, Begen MA. Working from home during the COVID-19 pandemic, its effects on health, and recommendations: the pandemic and beyond. Perspect Psychiatr Care 2021;11.

20 Anadón M, Savoie-Zajc L. La recherche-action dans certains pays anglo-saxons et latino-américains: une forme de Recherche participative. Recherches participatives: multiples regards 2007;1:13-30.

21 Michaud C, Bourgault P. Les devis de recherche non traditionnels. Fondements et étapes du processus de recherche: méthodes qualitatives et quantitatives, 2010: 371-2.

22 Larivière $\mathrm{N}$, Briand $\mathrm{C}$, Corbière $\mathrm{M}$. Les approches de recherche participatives: Illustration d'un partenariat pour l'amélioration des pratiques de réadaptation en santé mental au Québec. Méthodes qualitatives, quantitatives et mixtes dans la recherche en sciences humaines, sociales et de la santé, 2014: 649-75.

23 Maiter S, Simich L, Jacobson N. Reciprocity: an ethic for communitybased participatory action research. Action research 2008;6:305-25.

24 Camden C, Shikako-Thomas K, Nguyen T, et al. Engaging stakeholders in rehabilitation research: a scoping review of strategies used in partnerships and evaluation of impacts. Disabil Rehabil 2015;37:1390-400.

25 Woolf SH, Zimmerman E, Haley A, et al. Authentic engagement of patients and communities can transform research, practice, and policy. Health Aff 2016;35:590-4.

26 Achille M. Définir la santé au travail. II. Un modèle multidimensionnel des indicateurs de la santé au travail. Concilier performance organisationnelle et santé psychologique au travail, 2003: 91-112.

27 Keyes CLM. Subjective well-being in mental health and human development research worldwide: an introduction. Soc Indic Res 2006;77:1-10.

28 Gilbert M-H, Dagenais-Desmarais V, Savoie A. Validation d'une mesure de santé psychologique au travail. Eur Rev Appl Psychol 2011:61:195-203.

29 Larivière N. Analyse du concept de la participation sociale : définitions, cas d'illustration, dimensions de l'activité et indicateurs. Canadian Journal of Occupational Therapy 2008;75:114-27.

30 Dagenais-Desmarais V, Savoie A. What is psychological well-being, really? A grassroots approach from the organizational sciences. $J$ Happiness Stud 2012;13:659-84.

31 Desrosiers $\mathrm{J}$, Larivière $\mathrm{N}$. Le groupe de discussion focalisé. In: Corbière M, Larivières N, eds. Méthodes qualitatives, quantitatives et mixtes. Québec: Presses de I'Université du Quénec, 2014: 257-81.

32 Onwuegbuzie AJ, Dickinson WB, Leech NL, et al. A qualitative framework for collecting and analyzing data in focus group research. Int J Qual Methods 2009;8:1-21.

33 Barbour R. Doing focus groups: SAGE, 2008.

34 Guest G, Namey E, McKenna K. How many focus groups are enough? building an evidence base for nonprobability sample sizes. Field methods 2017;29:3-22.

35 Paillé P, Mucchielli A. L'analyse qualitative en sciences humaines et sociales. 4 edn. Paris: Armand Colin, 2016.

36 Leiter MP, Maslach C. Areas of worklife: a structured approach to organizational predictors of job burnout. In: Emotional and physiological processes and positive intervention strategies. Emerald Group Publishing Limited, 2003.

37 Sonnentag S, Fritz $\mathrm{C}$. The recovery experience questionnaire: development and validation of a measure for assessing recuperation and unwinding from work. J Occup Health Psychol 2007;12:204.

38 InField AP, Field AP. Discovering statistics using IBM SPSS statistics : and sex and drugs and rock ' $n$ ' roll. 4 edn. Los Angeles: SAGE, 2013.

39 Albert V, Durand M-J, Pepin G. TRIAGE: une technique structurée sollicitant l'opinion d'experts en vue d'atteindre un consensus. Méthodes qualitatives, quantitatives et mixtes appliquées au domaine de la santé mentale et d'autres domaines connexes, 2014: 305-26.

40 Gervais M, Pépin G. Triage: a new group technique gaining recognition in evaluation. Eval $J$ Australas 2002;2:45-9. 